\title{
PERLINDUNGAN HAK ASASI MANUSIA PENGUNGSI DAN PENCARI SUAKA DI INDONESIA ${ }^{1}$
}

\author{
Rahayu*, Kholis Roisah, Peni Susetyorini \\ Fakultas Hukum Universitas Diponegoro \\ Jl. Prof. Soedarto, SH, Tembalang, Semarang \\ rahayu_undip@yahoo.com
}

\begin{abstract}
This study further examines the protection of human rights of refugees and asylum seekers in Indonesia using a socio legal approach. The data used in the form of primary and secondary data obtained by observation, in-depth interviews and bibliography studies are subsequently analyzed in an inductive qualitative manner. This study concluded that although Indonesia has not ratified the Refugee Convention 1951 and Protocol 1967, but still has the obligation and responsibility to protect the human rights of refugees and asylum seekers residing in the territory of Indonesia. Through the Presidential Decree Number 125 Year 2016 on the Handling of Refugees from Abroad, the Government of Indonesia has a very strong alignments on the fulfillment of human rights of refugees and asylum seekers entering Indonesia by applying the principle of non-refoulement.
\end{abstract}

Keywords: Protection of Human Rights; Refugees; Asylum Seekers

\begin{abstract}
Abstrak
Penelitian ini bertujuan untuk mengkaji tentang perlindungan hak asasi manusia pengungsi dan pencari suaka di Indonesia dengan menggunakan pendekatan sociolegal. Data yang digunakan berupa data primer dan sekunder yang diperoleh dengan cara pengamatan, wawancara mendalam dan studi pustaka yang selanjutnya dianalisis secara induktif kualitatif. Studi ini menyimpulkan bahwa meskipun Indonesia belum meratifikasi Konvensi Pengungsi 1951 dan Protokol 1967, namun tetap memiliki kewajiban dan tanggung jawab untuk melindungi hak asasi manusia para pengungsi dan pencari suaka yang berada di wilayah Indonesia. Melalui Perpres Nomor 125 tahun 2016 tentang Penanganan Pengungsi dari Luar Negeri, Pemerintah Indonesia memiliki keberpihakan yang sangat kuat terhadap pemenuhan hak asasi manusia para pengungsi dan pencari suaka yang masuk ke wilayah Indonesia dengan menerapkan prinsip non-refoulement.
\end{abstract}

Kata Kunci: Perlindungan HAM; Pengungsi; Pencari Suaka

\footnotetext{
${ }^{1}$ Ditulis berdasarkan penelitian yang berjudul: "Kebijakan Penerapan Prinsip Non Refoulement dalam Rangka Penanganan Pengungsi Luar Negeri di Indonesia" yang dibiayai oleh Dana Selain APBN Fakultas Hukum Universitas Diponegoro tahun 2017.
} 


\section{A. Pendahuluan}

Perpindahan penduduk, baik di dalam wilayah suatu negara maupun yang melintasi batas negara, merupakan peristiwa yang telah lama ada dalam sejarah manusia dan semakin sering terjadi sekarang ini (Weiner, 1997). Pada prinsipnya, setiap orang memiliki hak untuk berpindah dari satu tempat ke tempat lainnya, termasuk meninggalkan negaranya sendiri dan kembali ke negaranya (Pasal 13 UDHR). Bahkan setiap orang dijamin haknya untuk mencari dan mendapatkan suaka di negara lain guna melindungi dirinya dari pengejaran (Pasal 14 ayat (1) UDHR). Perlindungan semacam ini tidak berlaku untuk kasus pengejaran yang timbul karena perbuatan kriminal dan perbuatan yang bertentangan dengan tujuan dan dasar PBB (Pasal 14 ayat (2) UDHR).

Salah satu bentuk perpindahan penduduk adalah pengungsian, baik lintas negara maupun di dalam wilayah negara (Internal Displace Person). Pengungsian merupakan bentuk perpindahan penduduk yang mempunyai cirri berbeda dengan perpindahan penduduk lainnya, sehingga berpengaruh terhadap mekanisme perlindungan yang diterapkan kepada mereka (Patrnogic, 1996). Pada umumnya, seorang pengungsi yang belum diakui statusnya akan dinamakan sebagai pencari suaka, tetapi seorang pencari suaka belum tentu adalah seorang pengungsi. Apabila seseorang diakui sebagai pengungsi maka akan melekat hak dan kewajiban sebagai pengungsi terhadap negara pelindungnya (Hardjaloka, 2015).

Para pengungsi ini, khususnya pengungsi lintas Negara atau pengungsi yang berasal dari luar negeri (selanjutnya disebut 'pengungsi'), biasanya tidak memiliki dokumen perjalanan lengkap, sehingga banyak di antara mereka mengalami perlakuan sewenang-wenang di negara tujuan atau negara transit seperti penyiksaan, perkosaan, diskriminasi, dan juga pemulangan secara paksa (Sakharina, 2013). Bahkan beberapa negara yang merupakan peserta Konvensi Pengungsi
1951 telah mengusir pengungsi untuk tidak masuk ke wilayahnya dengan alasan karena mereka mengancam keamanan nasional atau mengganggu ketertiban umum di negara tersebut (Yustinar, 2011).

Pemerintah Perancis pernah mengeluarkan kebijakan menyapu bersih semua pendatang dari kota Calais, kota yang dianggap penuh masalah dengan para pendatang gelap. Polisi membongkar kampkamp dan mencegah para pendatang mendirikan tenda, bahkan mereka mengambil selimut atau benda-benda lainnya lalu membuangnya. Hal ini dilakukan tanpa melihat dan mencari tahu terlebih dahulu bahwa di antara para pendatang yang diusir tersebut juga terdapat pencari suaka yang memiliki hak menunggu keputusan atas permohonan suaka mereka di Perancis. Demikian pula dengan yang dilakukan oleh Petugas Imigrasi Australia yang telah mengusir manusia perahu yang berisi pengungsi dari Bangladesh, Myanmar, dan Sri Langka dengan membayar kapten kapal sebesar 5000 dollar Australia untuk membawa perahu mereka masuk ke perairan Indonesia (Wagiman, 2012). Pengungsi Rohingya yang terpaksa harus meninggalkan negaranya Myanmar karena tindak kekerasan yang mereka alami, mendapatkan perlakuan kasar dan pemulangan secara paksa oleh Pemerintah Thailand, ketika mereka berusaha mencari perlindungan. Pemerintah Thailand telah mengirim pulang secara paksa sekitar 1.300 pengungsi muslim Rohingya ke negara asal mereka.

Bagi negara penerima, arus pengungsian yang terus menerus masuk ke wilayahnya, selain merupakan masalah kemanusiaan ternyata juga berdampak pada bidang keamanan, ekonomi dan keseimbangan sosial politik di negara tersebut (Loescher, 1993). Itulah sebabnya, meskipun bertentangan dengan prinsip nonrefoulement, di dalam praktek masih ditemui negara yang menolak pencari suaka atau pengungsi masuk ke wilayahnya bahkan memulangkannya secara paksa. 
Dilihat dari perspektif Hukum Internasional, sikap negara-negara yang menolak pengungsi masuk ke wilayahnya tersebut sebenarnya dapat dipahami dari sisi kedaulatan negara, bahwa setiap negara boleh menolak atau menerima orang asing masuk ke wilayahnya. Sikap ini juga merupakan langkah preventif sebagai bentuk pertahanan negara dari gangguan asing, di samping upaya untuk melindungi dan menjaga stabilitas ekonomi dan politik negara tersebut. Namun di sisi lain juga ada prinsip Hukum Hak Asasi Manusia yang harus dihormati, seperti prinsip kewajiban negara untuk melindungi setiap orang yang terancam jiwanya dan hak setiap orang untuk mendapat perlindungan kemanusiaan dimana pun ia berada.

Indonesia memiliki pengalaman menangani lebih dari 120 ribu orang pengungsi manusia perahu asal Vietnam pada tahun 1979-1996. Para pengungsi ini merupakan titipan dari beberapa negara tetangga untuk diproses status pengungsinya sebelum dikirim ke negara ketiga atau dipulangkan ke negara asalnya. Mereka ditempatkan di Pulau Galang, Provinsi Kepulauan Riau dalam 140 barak. Bekerja sama dengan UNHCR dan badan khusus PBB lainnya, seluruh pengungsi tersebut akhirnya selesai direpatriasi pada tanggal 30 Juni 1996.

Pengalaman tersebut ternyata belum cukup bagi Indonesia untuk menangani masalah pengungsi dan pencari suaka yang jumlahnya terus meningkat saat ini. Akibatnya, tidak saja dirasakan oleh para pengungsi yang berada dalam situasi ketidakpastian akan masa depannya, tapi juga dirasakan oleh Pemerintah Indonesia pada besarnya potensi ancaman dan gangguan keamanan, ketertiban dan kedaulatan Indonesia.

Jumlah pengungsi dan pencari suaka di Indonesia yang terus meningkat ini dapat dilihat pada tabel berikut ini:

Tabel 1.

Jumlah Pengungsi dan Pencari Suaka di Indonesia

\begin{tabular}{ccccc}
\hline Status Pengungsi & $\mathbf{2 0 1 2}$ & $\mathbf{2 0 1 6}$ & $\mathbf{2 0 1 7}$ & $\mathbf{2 0 1 9}$ \\
\hline Pengungsi & 1.288 & 8.039 & 9.279 & 10.729 \\
Pencari Suaka & 5.900 & 6.386 & 4.424 & 3.298 \\
Total & 7.188 & 14.425 & 13.703 & 14.027 \\
\hline
\end{tabular}

Sumber: Ditjen Imigrasi, Kemenkumham, Maret 2019

Tingginya arus pengungsi dan pencari suaka yang masuk ke wilayah Indonesia ini didorong oleh beberapa faktor, baik internal maupun eksternal, di antaranya adalah: (1) Kondisi geografis Indonesia sebagai negara kepulauan dengan wilayah laut yang luas dan garis pantai yang panjang, namun tidak didukung oleh aturan hukum yang tegas. Masih banyak wilayah laut dan perbatasan yang tak terjaga serta tidak memiliki tempat pemeriksaan imigrasi, sehingga dengan mudah dimanfaatkan bagi para pengungsi dan pencari suaka untuk memasuki wilayah Indonesia; (2) Sikap Indonesia yang dianggap sangat lemah dalam mengatasi masalah para pengungsi dan pencari suaka dari negara lain, karena tidak memiliki peraturan nasional yang secara khusus mengatur hal tersebut. Akibatnya, terjadi tumpang-tindih dan tidak jelasnya tugas lembaga-lembaga yang terkait dalam penanganan masalah pengungsi dan pencari suaka; (3) Keberadaan UNHCR di Jakarta juga menjadi daya tarik tersendiri bagi pengungsi dan pencari suaka. Mereka merasa aman memasuki wilayah Indonesia, karena setiap imigran gelap yang menyatakan dirinya sebagai pengungsi atau pencari suaka akan langsung dirujuk kepada UNHCR; (4) Kultur atau budaya masyarakat 
Indonesia yang dikenal dengan keramahannya, menimbulkan kesan masyarakat Indonesia dapat dengan mudah menerima kedatangan dan keberadaan para pengungsi yang mayoritas muslim.

Di samping faktor internal di atas, meningkatnya jumlah pengungsi dan pencari suaka di Indonesia ini juga disebabkan oleh faktor eksternal, antara lain kebijakan Pemerintah Australia, "The Pacific Solution" (tahun 2001-2007), yang menolak pengungsi masuk ke wilayahnya, baik secara resmi maupun tidak resmi. Kebijakan ini berdampak pada ribuan calon pengungsi dari wilayah Asia Tengah dan Timur Tengah yang sedang berkonflik dan ingin meninggalkan negaranya untuk mengungsi ke Australia. Mereka terkatung-katung di tengah laut antara Indonesia dan Australia, dan atas alasan kemanusiaan mereka diselamatkan ke wilayah Indonesia.

Terkait dengan pemenuhan hak asasi manusia para pengungsi, maka pada bulan Maret 1997 Amnesty International pernah mengemukakan 3 (tiga) masalah utama yang selalu dihadapi para pengungsi dan hampir selalu diabaikan oleh negara/Pemerintah di dunia (Lambert, 2012), baik di negara asal, di negara pemberi suaka maupun di tingkat internasional. Negara asal pengungsi adalah negara yang memiliki kewajiban dan tanggung jawab untuk melindungi setiap warga negaranya dimana pun berada, termasuk kewajiban untuk menciptakan kondisi agar warga negaranya tidak dipaksa untuk meninggalkan negaranya sendiri untuk mencari tempat yang aman di negara lain. Sementara itu, negara pemberi suaka memiliki kewajiban untuk meyakinkan bahwa para pengungsi dan pencari suaka yang dilanggar hak asasinya tersebut dijamin haknya untuk mendapatkan rasa aman dan memperoleh perlindungan efektif dari pemulangan kembali secara paksa (refoulement). Sedangkan di tingkat internasional, negara-negara di dunia wajib mendasarkan semua kebijakannya dalam menangani pengungsi di wilayahnya ini pada prinsip perlindungan hak asasi manusia.
Sebagai bagian warga dunia, Indonesia juga terikat pada berbagai ketentuan hukum internasional, baik yang bersumber pada perjanjian internasional maupun hukum kebiasaan internasional termasuk yang mengatur tentang pengungsi. Berdasar latar belakang tersebut, maka artikel ini akan mengkaji lebih lanjut tentang perlindungan hak asasi manusia pengungsi dan pencari suaka di Indonesia.

\section{B. Metode Penelitian}

Penelitian ini menggunakan pendekatan sosio-legal yang mengkombinasikan antara pendekatan hukum dan pendekatan ilmu sosial. Pendekatan ini digunakan untuk mendalami suatu masalah dengan tidak terbatas pada norma atau doktrin hukum, tapi juga melihat secara lengkap konteks norma dan pemberlakuannya (implementasinya). Pendekatan kombinatif ini diharapkan dapat memperkuat upaya pencarian kebenaran dengan lebih kreatif dan membebaskan.

Data yang digunakan berupa data primer dan data sekunder yang diperoleh dengan cara pengamatan, wawancara mendalam dan studi pustaka. Selanjutnya data diklasifikasi dan setelah data hasil penelitian dianggap valid dan reliable, maka akan dianalisis secara induktif-kualitatif untuk menjawab permasalahan yang menjadi fokus studi penelitian ini.

\section{Hasil dan Pembahasan}

\section{Pengungsi dan Pencari Suaka dalam Hukum Internasional}

Meskipun sampai saat ini belum ada instrumen Hukum Internasional yang memberikan pengertian tentang suaka, secara umum suaka (asylum) diartikan sebagai perlindungan yang diberikan oleh suatu negara kepada individu yang memintanya berdasarkan alasan peri kemanusiaan, agama, diskriminasi ras, politik dan sebagainya (Sulaiman, 2002). Menurut J.G. Starke, suaka memiliki 2 (dua) elemen, yaitu tempat perlindungan dan suatu usaha perlindungan aktif sebagai bagian 
kewenangan pemegang kekuasaan di wilayah teritorial dimana suaka tersebut diberikan (Starke, 1997). Seorang pengungsi yang belum diakui statusnya disebut sebagai pencari suaka, namun seorang pencari suaka belum tentu seorang pengungsi, karena permintaan mereka akan perlindungan belum selesai diproses.

Sampai saat ini, instrumen Hukum Internasional yang khusus mengatur tentang suaka masih berbentuk deklarasi, yaitu 'The Universal Declarationon Teritorial Asylum 1967' yang disahkan Majelis Umum PBB pada 14 Desember 1967 dalam Resolusi 2312 (XXII). Deklarasi suaka territorial ini, meskipun tidak bersifat mengikat secara hukum (non-legally binding), namun tetap memiliki makna yang sangat penting mengingat di antara para pengungsi itu mungkin saja terdapat orang-orang yang mencari suaka (asylum seekers).

Deklarasi tersebut didasarkan pada Pasal 13 dan Pasal 14 Universal Declaration of Human Rights (UDHR) yang memberikan jaminan hak bagi setiap orang untuk mencari suaka karena persekusi, serta hak untuk pergi dan kembali ke negaranya. Secara garis besar Deklarasi ini mengatur tentang pembatasan pemberian suaka teritorial, larangan bagi negara menolak pencari suaka di perbatasan kecuali bila jumlahnya sangat besar (influx of persons) sehingga mengancam keamanan negaranya, serta berisi hal-hal yang tidak boleh dilakukan oleh mereka yang mendapat suaka.

Sedangkan pengertian pengungsi dapat dirujuk pada Pasal 1 A (2) Konvensi 1951 tentang Status Pengungsi yang menyatakan bahwa pengungsi adalah:

“...as a result of events occurring before 1 January 1951 and owing to well-founded fear of being persecuted for reasons of race, religion, nationality, membership of a particular social group or political opinion, is outside the country of his nationality and is unable or, owing to such fear, is unwilling to avail himself of the protection of that country; or who, not having a nationality and being outside the country of his former habitual residence as a result of such events, is unable or, owing to such fear, is unwilling to return toit..."

Berdasar pengertian tersebut, beberapa unsur yang harus diperhatikan agar seseorang dapat disebut sebagai pengungsi adalah (Kneebone, Susan; Stevens, Dallal, and Baldassar, 2014): (a) Well-founded fear, bahwa rasa takut tersebut harus objektif dan benar-benar berdasarkan fakta yang realistis; (b) Persecution, bahwa terdapat ancaman terhadap nyawa dan kemerdekaan pribadinya (sangat berkaitan dengan pelanggaran hak asasi manusia); (c) Convention grounds, yaitu alasan-alasan berdasar Konvensi 1951, meliputi karena alasan ras, agama, kebangsaan, keanggotaan pada kelompok masyarakat atau karena perbedaan paham politik; (d) Outside the country of nationality or habitual residence, artinya bahwa dia tidak berada dalam wilayah negaranya, tapi pergi melintasi batas wilayah negaranya; (e) Unable or unwilling to avail himself of state protection, bahwa dia tidak mau meminta perlindungan kepada negaranya sendiri atau negaranya tidak memberikan perlindungan terhadap mereka.

Pengertian pengungsi seperti dirumuskan Pasal 1 A (2) Konvensi 1951 tersebut hanya berlaku bagi mereka yang menjadi pengungsi akibat peristiwa sebelum tanggal 1 Januari 1951. Guna mengakomodir persoalan pengungsi yang terjadi setelah Perang Dunia II, terutama pengungsi yang timbul karena konflik politik di Afrika tahun 1950-an dan tahun1960-an, maka Konvensi 1951 yang memberikan batasan waktu (date line) dan wilayah (geographical limitation) untuk pengungsi yang terjadi di Eropa sebelum 1 Januari 1951 atau kejadian yang terjadi di Eropa atau dimana saja sebelum 1 Januari 1951, direvisi dengan Resolusi Majelis Umum PBB 2198 (XXI) 1966 tentang Status Pengungsi yang dikenal dengan Protokol tentang Status Pengungsi 1967 yang mulai berlaku 4 Oktober 1967. Pengertian 
pengungsi dalam Protokol ini tidak lagi dibatasi pada peristiwa sebelum 1951. Pasal 1 ayat (2) Protokol tersebut menghapuskan kata-kata "...as a result of events occuring before 1 Januari 1951" dan kata-kata ".... as a result of such events" yang terdapat pada Konvensi 1951.

Isi Konvensi 1951 dan Protokol 1967 pada prinsipnya hampir sama. Ada tiga hal pokok yang diatur oleh Konvensi dan Protokol tersebut, yaitu: (a) Pengertian dasar pengungsi yang diperlukan untuk menetapkan status seseorang termasuk pengungsi atau bukan. Bagi negara-negara yang sudah meratifikasi Konvensi 1951 dan/atau Protokol 1967, maka penetapan dilakukan oleh negara tempat orang itu berada, bekerja sama dengan UNHCR. Sedang bagi negara yang belum meratifikasi, penetapan tersebut dilakukan oleh Perwakilan UNHCR di negara tersebut; (b) Status hukum, hak dan kewajiban pengungsi di negara tempat pengungsian; (c) Implementasi (pelaksanaan) perjanjian, terutama menyangkut administrasi dan hubungan diplomatik, khususnya hal-hal yang menyangkut kerjasama dengan UNHCR untuk melakukan tugas pengawasan terhadap negara-negara dimana pengungsi itu berada.

Terkait dengan hak dan kewajiban pengungsi, Konvensi 1951 menegaskan hak pengungsi sebagai berikut: (a) Hak untuk tidak diperlakukan secara diskriminatif, Pasal 3 dan 4 Konvensi 1951 menegaskan bahwa Negara-negara peserta Konvensi tidak boleh memperlakukan pengungsi berdasarkan politik diskriminasi, baik berdasarkan ras, agama, negara asal maupun warna kulit; (b) Hak milik, Pasal 13, 14, dan 30 Konvensi 1951 mengatur bahwa seorang pengungsi mempunyai hak yang sama untuk mempunyai atau memiliki hak milik, baik bergerak maupun tidak bergerak dan menyimpannya seperti halnya orang lain. Di samping itu pengungsi juga dapat mentransfer asetnya ke negara dimana dia akan menetap; (c) Hak berserikat, Negara peserta Konvensi harus mengakui kebebasan pengungsi untuk berserikat dengan mendirikan perkumpulan, termasuk perkumpulan dagang sepanjang perkumpulan itu bersifat non-profit dan nonpolitis (Pasal 15 Konvensi 1951); (d) Hak berperkara di Pengadilan, Dalam hal pengungsi mengalami suatu perkara dan ingin menyelesaikannya melalui badan peradilan, maka mereka harus dianggap sama dengan warga negara lainnya. Artinya, mereka memiliki kebebasan untuk mengajukan gugatannya pada pengadilan dimana mereka tinggal. Bahkan bila diperlukan mereka dapat memperoleh bantuan hukum (Pasal 16 Konvensi 1951); (e) Hak atas pekerjaan, Konvensi 1951 memberikan hak kepada pengungsi yang telah ditempatkan secara tetap di suatu negara dan telah diakui menurut hukum untuk mendapatkan pekerjaan serta mendirikan suatu perusahaan dagang dan pekerjaan bebas lainnya yang sesuai dengan ketentuan yang berlaku (Pasal 17, 18 dan 19); (f) Hak atas kesejahteraan social, Pasal 20 dan 22 Konvensi 1951 mengatur bahwa setiap pengungsi akan dapat menikmati hak-hak atas kesejahteraan sosial, seperti hak untuk bekerja, perumahan, mendapatkan upah dari pekerjaan yang mereka lakukan; (g) Hak atas pendidikan dan pengajaran, Setiap pengungsi berhak mendapat perlakuan yang sama dengan warga Negara lainnya untuk memperoleh pendidikan di sekolah dasar, termasuk hak atas pembebasan biaya pendidikan tertentu termasuk juga hak untuk memperoleh beasiswa (Pasal 22); (h) Hak kebebasan bergerak, Setiap pengungsi memiliki kebebasan yang seluas-luasnya untuk memilih di daerah mana mereka akan menetap, sepanjang pilihan itu masih berada dalam teritorial negara dimana ia ditempatkan (Pasal 26 Konvensi 1951); (i) Hak atas tanda pengenal dan dokumen perjalanan, Pasal 27 dan 28 Konvensi 1951 menentukan bahwa setiap pengungsi berhak atas surat-surat identitas dan dokumen perjalanan keluar dari teritorial negara dimana dia ditempatkan, kecuali karena alasan keamanan dan kepentingan umum. Dokumen perjalanan yang dikeluarkan ini 
diakui oleh negara peserta Konvensi; (j) Hak non-refoulement, Bahwa negara tidak diperbolehkan mengusir ataupun mengembalikan pengungsi dengan cara apapun ke perbatasan wilayah-wilayah dimana kehidupan atau kebebasannya akan terancam karena ras, agama, keanggotaan pada kelompok social tertentu atau karena opini politiknya (Pasal 33 ayat (1) Konvensi 1951); (k) Hak status pribadi, Berdasarkan Pasal 12 Konvensi 1951, status pribadi para pengungsi diatur sesuai dengan hukum dimana mereka berdomisili. Jika mereka tidak mempunyai domisili, status pribadi mereka diatur oleh hukum dimana mereka ditempatkan (place of residence). Termasuk hak atas status pribadi ini adalah hak yang berkaitan dengan perkawinan.

Selain hak-hak pengungsi yang disebutkan di atas, Konvensi juga menggariskan kewajiban pengungsi sebagaimana tercantum dalam Pasal 2 Konvensi 1951 bahwa “...Every refugee has duties to the country in which he finds himself, which require in particular that he conform to its laws and regulations as well as to measures taken for maintenance of public order...". Artinya bahwa setiap pengungsi berkewajiban untuk mematuhi semua hukum dan peraturan atau ketentuanketentuan untuk menciptakan ketertiban umum di negara dimana dia ditempatkan.

\section{Penanganan Pencari Suaka dan Pengungsi di Indonesia}

Berdasarkan data dari Direktorat Jenderal (Ditjen) Imigrasi Kementerian Hukum dan HAM, sampai dengan bulan Maret 2019 terdapat sekitar 14.027 orang yang terdiri dari 10.729 orang pengungsi dan 3.298 orang pencari suaka di Indonesia yang berasal dari 17 negara. Mereka terdiri dari 9.563 orang laki-laki dan 4.464 orang perempuan. Dari jumlah tersebut, 5.552 orang diantaranya merupakan pengungsi mandiri, sedang 8.475 orang lainnya merupakan pengungsi dan/atau pencari suaka yang tinggal di tempat penampungan sementara (biasanya adalah rumah detensi di bawah Ditjen Imigrasi Kementerian Hukum dan HAM), yang terdapat di 8 (delapan) kota di Indonesia, dengan sebaran sebagai berikut:

Tabel 2.

Sebaran Wilayah Keberadaan Pengungsi di Tempat Penampungan Sementara (per Maret 2019)

\begin{tabular}{cc}
\hline Kota & Jumlah \\
\hline Medan & 2.106 \\
Makassar & 1.825 \\
Jakarta & 1.674 \\
Pekan Baru & 1.125 \\
Tanjung Pinang & 998 \\
Surabaya & 384 \\
Kupang & 270 \\
Semarang & 93 \\
Total & 8.475 \\
\hline Sumber: & Ditjen Imigrasi, Kemenkumham, Maret \\
2019. &
\end{tabular}

Mereka berasal dari 17 negara di Asia dan Afrika, dengan rincian sebagai berikut:

Tabel 3.

Kebangsaan Pengungsi yang berada di Tempat Penampungan Sementara (per Maret 2019)

\begin{tabular}{cc}
\hline Negara & Jumlah \\
\hline Afghanistan & 4.825 \\
Somalia & 1.099 \\
Myanmar & 608 \\
Srilanka & 440 \\
Sudan & 398 \\
Palestina & 350 \\
Irak & 249 \\
Pakistan & 164 \\
Iran & 156 \\
Ethiopia & 87 \\
Eritrea & 31 \\
Yaman & 22 \\
Vietnam & 20 \\
Mesir & 12 \\
Suriah & 9 \\
Yordania & 3 \\
Bangladesh & 2 \\
Total & 8.475 \\
\hline Sumber: & Ditjen Imigrasi, Kemenkumham, Maret \\
2019. &
\end{tabular}


Lalu lintas orang yang masuk dan keluar wilayah Indonesia dan pengawasannya ini sangat berkaitan erat dengan fungsi keimigrasian. Menurut UU No. 6 Tahun 2011 tentang Keimigrasian, setiap orang asing yang akan masuk ke wilayah Indonesia wajib memiliki visa. Mereka akan diperiksa oleh pejabat imigrasi di Tempat Pemeriksaan Imigrasi (TPI) untuk mendapatkan tanda masuk/tanda keluar oleh petugas imigrasi, atau mendapat ijin tinggal di wilayah Indonesia. Orang asing yang mendapatkan ijin tinggal di wilayah Indonesia ini, keberadaannya harus sesuai dengan maksud dan tujuannya, memberikan manfaat serta tidak membahayakan keamanan dan ketertiban umum (selective policy).

Jika terdapat orang asing yang tidak memenuhi persyaratan maka yang bersangkutan tidak diperkenankan masuk ke wilayah Indonesia. Bila pada saat pemeriksaan di TPI terdapat orang asing yang meminta perlindungan (asylum), maka penting untuk mencermati Pasal 14 ayat 1 Universal Declaration of Human Rights 1948, bahwa "...everyone has the right to seek and to enjoy in other countries asylum from persecution...". Pasal 14 ayat 2 membatasi kata "enjoy", bahwa "...this right many not be invoke in the case of prosecution genuinely arising from nonpolitical crimes or from acts contrary to the purpose and principle of the United Nation...", artinya sejauh bukan kejahatan politik dan kejahatan yang bertentangan dengan prinsip-prinsip yang dimuat dalam Piagam Perserikatan Bangsa-Bangsa (PBB), maka kepada mereka dapat diberikan perlindungan internasional. Praktek seperti ini lazim dan umum di seluruh dunia dilakukan oleh petugas imigrasi di TPI, karena hal tersebut telah menjadi hukum kebiasaan dan praktek internasional.

Menurut Pasal 2 ayat (2) Peraturan Direktur Jenderal Imigrasi Nomor IMI0352.GR.02.07, setiap orang asing yang menyatakan diri sebagai pencari suaka atau pengungsi pada saat masuk ke wilayah Indonesia, maka pada kesempatan pertama saat masuk ke wilayah Indonesia dilakukan penanganan dengan: (a) Melakukan pengamanan dan pendataan; (b) Menghubungi perwakilan negara orang asing tersebut; (c) Menghubungi IOM untuk fasilitas penampungan sementara; dan (d) Menghubungi UNHCR untuk penentuan statusnya.

Penanganan oleh Pejabat Imigrasi di TPI tersebut sebagai upaya kemanusiaan dalam memberikan perlindungan (asylum), karena mereka adalah kelompok rentan terhadap perlakuan yang tidak manusiawi, baik di negara asalnya maupun di negara tempat mereka mengungsi. Upaya tersebut sesuai dengan kampanye Amnesty International untuk hak asasi manusia pengungsi yang dicanangkan sejak bulan Maret 1997, yaitu bahwa negara tempat pengungsi berada diperbolehkan mencarikan tempat yang aman, diberikan perlindungan yang efektif dan hak asasi mereka dihormati.

Setelah regulasi tersebut diimplementasikan pada tanggal 19 April 2016, maka telah terjadi peningkatan yang cukup signifikan jumlah pengungsi dan pencari suaka yang masuk ke wilayah Indonesia. Bila pada tahun 2016 terdapat 8.039 orang pengungsi, pada tahun 2017 meningkat menjadi 9.279 orang dan pada tahun 2019 menjadi 10.729 orang. Sementara itu jumlah pencari suaka jumlahnya semakin berkurang dari 6.386 orang pada tahun 2016 menjadi 4.424 orang pada tahun 2017 dan 3.298 orang pada tahun 2018. Berdasar data tersebut, maka tampak jelas bahwa Peraturan Direktur Jenderal Imigrasi tersebut telah menjadi faktor penarik (pull factor) bagi orang asing untuk meminta perlindungan (asylum) dan menjadi pengungsi di wilayah Indonesia, dimana pada umumnya mereka masuk melalui TPI Bandar Udara.

Besarnya arus pengungsi dari tahun ke tahun yang masuk ke wilayah Indonesia (lihat Tabel 1), ternyata tidak seimbang dengan jumlah yang berhasil ditempatkan ke negara ketiga (resettlement) atau dikembalikan ke negaranya secara suka rela (AVR: Assisted Voluntary Returned) yang 
jumlahnya cenderung turun dari tahun ke tahun. Hal ini dapat dilihat pada tabel di bawah ini:

Tabel 4.

Penempatan Pengungsi ke Negara Ketiga (resettlement) dan Assisted Voluntary Returned (AVR) tahun 2009-2019

\begin{tabular}{lcccccc}
\hline Program & $\mathbf{2 0 0 9}$ & $\mathbf{2 0 1 2}$ & $\mathbf{2 0 1 6}$ & $\mathbf{2 0 1 7}$ & $\mathbf{2 0 1 8}$ & $\mathbf{2 0 1 9}$ \\
\hline Resettlement & 108 & 119 & 1.286 & 754 & 568 & 136 \\
AVR & 162 & 130 & - & 495 & 436 & 70 \\
\hline
\end{tabular}

Sumber: Ditjen Imigrasi, Kemenkumham, Maret 2019

\section{Kebijakan Penanganan Pengungsi dan Pencari Suaka di Indonesia yang Berperspektif Hak Asasi Manusia (HAM)}

Pada dasarnya masalah yang dihadapi oleh pengungsi dan pencari suaka di samping masalah kemanusiaan adalah juga masalah hubungan antar negara. Itulah sebabnya penanganan masalah ini dilakukan dengan semaksimal mungkin menghindarkan terganggunya hubungan baik antara Pemerintah Indonesia dengan negara asal para pengungsi dan pencari suaka. Sesuai dengan Pasal 27 ayat (2) UU Nomor 37 Tahun 1999 tentang Hubungan Luar Negeri, dalam menangani pengungsi dan pencari suaka ini Pemerintah Indonesia melalui Kementerian Luar Negeri akan berkoordinasi dengan organisasi internasional terkait, dalam hal ini UNHCR dan IOM.

Indonesia sampai saat ini belum meratifikasi Konvensi Pengungsi 1951 maupun Protokol 1967, artinya tidak memiliki kewajiban hukum terikat pada kedua perjanjian internasional tersebut. Namun demikian, sebagai bagian dari masyarakat internasional, Indonesia harus tetap menghormati hukum kebiasaan internasional dan prinsip-prinsip hukum yang berlaku terkait pengungsi dan pencari suaka. Salah satu di antaranya adalah prinsip non-refoulement, yaitu prinsip yang menegaskan larangan atau tidak diperbolehkannya suatu negara untuk mengembalikan atau mengirimkan pengungsi (refugee) ke suatu wilayah tempat dia akan menghadapi persekusi atau penganiayaan yang membahayakan hidupnya karena alasan-alasan yang berkaitan dengan ras, agama, kebangsaan, keanggotaan pada kelompok sosial tertentu, atau karena keyakinan politiknya. Prinsip ini juga berlaku bagi pengungsi yang berada di negara bukan peserta Konvensi (Pasal 1 A Konvensi Pengungsi 1951).

Sesuai dengan prinsip tersebut maka Pemerintah Indonesia memiliki komitmen yang sangat kuat untuk melindungi para pengungsi dan pencari suaka yang masuk ke wilayah Indonesia. Hal ini dapat dilihat dalam berbagai kebijakan hukumnya, baik dalam Konstitusi, UU maupun peraturan pelaksana lainnya. Salah satu di antaranya adalah Peraturan Presiden Nomor 125 Tahun 2016 tentang Penanganan Pengungsi dari Luar Negeri. Secara normatif, Perpres No. 125 Tahun 2016 ini mengisi kekosongan hukum pengaturan pengungsi dan pencari suaka di Indonesia sebagaimana yang ditegaskan di dalam Pasal 28G UUD dan Pasal 25, Pasal 26 dan Pasal 27 UU No. 37 Tahun 1999 tentang Hubungan Luar Negeri.

Perpres ini antara lain mengatur tentang pengamanan terhadap para pengungsi dan pencari suaka, koordinasi antara Pemerintah dengan UNHCR soal status mereka, serta menghormati kebebasan fundamental mereka. Di samping itu, Perpres ini juga memberikan perhatian khusus kepada kaum 
rentan yang berada dalam kondisi darurat di laut dan darat, sakit, hamil, difabel, anak, dan lanjut usia; memberikan pengakuan untuk penyatuan keluarga; kejelasan definisi pengungsi; distribusi peran antar lembaga dan prinsip berbagi tanggung jawab; dan penggunaan APBN untuk perlindungan pengungsi. Meskipun Perpres ini tidak melindungi semua hak asasi manusia pengungsi, seperti hak untuk bekerja dan menempuh pendidikan, namun Perpres tidak melarang mereka bersekolah atau bekerja.

Menurut Perpres ini, perumusan kebijakan penanganan pengungsi yang meliputi penemuan, penampungan, pengamanan dan pengawasan keimigrasian disampaikan kepada Menteri Koordinator Politik, Hukum dan Keamanan (Menkopolhukam) setelah mendapatkan pertimbangan dari Menteri Luar Negeri. Proses penanganannya dilakukan secara koordinatif oleh Menkopolhukam sesuai dengan tanggung jawab dan kewenangan masing-masing instansi. Peraturan Pemerintah ini tidak memberikan kewenangan mutlak kepada satu instansi saja, melainkan dilaksanakan secara bersama-sama sesuai dengan tanggung jawab dan kewenangan yang diberikan oleh peraturan perundang-undangan yang ada. Setiap kebijakan yang dibuat oleh instansi terkait harus dikoordinasikan dengan Menteri Luar Negeri sebelum diputuskan oleh Menkopolhukam.

Kondisi ini ternyata memunculkan kerumitan dan kesulitan dalam menyelesaikan permasalahan pengungsi dan pencari suaka. Kesulitan tersebut meliputi adiminstrasi, koordinasi, pengelolaan anggaran, personil, penggunaan sarana dan prasarana, manajemen dan leadership. Persoalan semakin rumit ketika beberapa negara tujuan para pengungsi mengubah kebijakan nasional keimigrasiannya dengan menutup wilayahnya menjadi negara tujuan, sehingga mengganggu program resettlement dan AVR (Assisted Voluntary Returned). Akibatnya para pengungsi ini tetap berada di wilayah Indonesia, hidup dalam ketidakpastian dan untuk jangka waktu yang tidak menentu. Terhadap masalah tersebut, UNHCR menawarkan solusi agar para pengungsi memiliki aktivitas dan dapat memenuhi kebutuhan dasar hidupnya, maka berdasarkan kerjasama yang dibuat bersama dengan masyarakat dan pengusaha, para pengungsi dapat dipekerjakan agar memperoleh penghasilan untuk menopang kebutuhan hidupnya. Selain itu, opsi asimilasi dengan negara tempat pengungsi berada juga menjadi pilihan lain yang disampaikan oleh UNHCR kepada Pemerintah Indonesia. Dibanding dengan peraturan-peraturan yang sudah ada sebelumnya, Perpres Nomor125 tahun 2016 ini memiliki keberpihakan yang sangat kuat terhadap pemenuhan hak asasi manusia para pengungsi dan pencari suaka yang masuk ke wilayah Indonesia dengan menerapkan prinsip non-refoulement. Pemenuhan hakhak pengungsi dan pencari suaka ini disesuaikan dengan kemampuan Pemerintah Indonesia dan sesuai dengan Standar Minimum Internasional sebagaimana diterima masyarakat internasional dalam Doktrin Calvo, bahwa warga negara asing hanya dapat menerima haknya tidak melebihi hak-hak yang diterima oleh warga negara tersebut.

\section{Simpulan}

Sampai saat ini Indonesia belum meratifikasi Konvensi Pengungsi 1951 dan Protokol 1967, namun tetap memiliki kewajiban dan tanggung jawab terhadap perlindungan hak asasi manusia para pengungsi dan pencari suaka yang berada di wilayah Indonesia. Kewajiban ini tidak saja merupakan kewajiban konstitusional, tapi juga pelaksanaan prinsip non-refoulement dan Doktrin Calvo yang diakui oleh negaranegara di dunia ini.

\section{DAFTAR PUSTAKA}

Hardjaloka, L. (2015). Studi Perbandingan Ketentuan Perlindungan Pencari Suaka dan Pengungsi di Indonesia dan Negara Lainnya (Comparative Study on Asylum Seeker and Refugees Protection 
Regulation in Indonesia and Other Countries). Jurnal Legislasi Indonesia, $12(1)$.

Kneebone, Susan; Stevens, Dallal, and Baldassar, L. (2014). Refugee Protection and the Role of Law: Conflicting Identities. Routdledge.

Lambert, H. (2012). Safe Third Country in the European Union: An Evolving Concept in International Law and Implications for the UK. Journal of Immigration, Asylum and Nationality Law, 4.

Loescher, G. (1993). Beyond Charity: International Cooperationand the Global Refugee Crisis. Oxford University Press.

Patrnogic, J. (1996). Introduction to International Refugee Law. Refugee Law Courses the International Institute of Humanitarian Law.
Sakharina, I. K. (2013). Pengungsi dan HAM. Jurnal Hukum Internasional Fakultas Hukum Universitas Hasanuddin, 2(1).

Starke, J. G. (1997). An Introduction to International Law. Butterworths.

Sulaiman, H. (2002). Lembaga Suaka dalam Hukum Internasional. Raja Grafindo Persada.

Wagiman. (2012). Hukum Pengungsi Internasional. Sinar Grafika.

Weiner, M. (1997). Global Movement, Global Walls: Responses to Migration 1885-1925. Gung Wu (ed). Global History and Migration. Westview Press.

Yustinar, J. (2011). Penerapan Prinsip Non Refoulement di Indonesia. Pustaka Perjanjian Internasional, 3. 